\title{
Aspects of Multicultural Marketing of Insurance Companies
}

\author{
by Ute Werner*
}

\section{Introduction}

"Multiculturalism" is an anthropological term used in Canada, Australia, New Zealand, and the United States to denote a social integration model which completes and extends former concepts, like the "melting pot". While maintaining cultural distinctions it tries to procure equal legal status for all men - citizens or immigrants. Likewise, multicultural marketing intends to take the cultural characteristics of human perception and human behaviour explicitly into consideration. Thus, it depicts an alternate concept to the so-called "global" marketing in as much as this strategy attempts to create products that can be offered globally, i.e., on various local markets, utilizing similar tools and procedures. The resulting standardization of products and techniques may, of course, have a cost saving impact on marketing and production. This, however, carries the risk that the standardized products might satisfy the desires and wants of their potential users only partially, if at all.

Therefore, marketing in the European context should be multiculturally oriented. This is particularly essential for areas in which norms and product standards are subject to processes of disintegration, as in the European Insurance Market.

- From July 1994 on there will be no more ex officio authorization of general insurance regulations and consequently less standardization of insurance products, even in household insurance, so that enforced product innovation can be expected.

- Products that are legitimally manufactured and marketed in one EC country have free access to the markets in the other member states.

- Although the process of blending national markets with foreign products might not take such a fast course as often expected, the market structures will change - in spite of different national settings in social insurance, tax systems, jurisdiction, in addition to different levels of interest rates, different market structures (e.g. in distribution), different languages, etc.

The situation in the European insurance market is therefore extremely complex. This does not have to represent a problem. Indeed it can provide a solution, as multicultural marketing explicitly considers the complexities inherent in cultural differences and seeks to develop policies that fit into the varied contexts.

* Institut für Betriebswirtschaftliche Risikoforschung und Versicherungswirtschaft, LudwigMaximilians-Universität München. 
We shall try to define the term "culture" and to demonstrate which cultural differences may be relevant for the insurance business. These differences illustrate the necessity of adapting marketing policy and techniques to a multicultural environment and to changing market conditions. Likewise, we want to show how the search for culture-specific solutions can be carried through and which problems may arise in this process. However, a complete marketing concept will not be elaborated upon.

\section{Relevance of cultural phenomenons for the insurance business}

\subsection{Culture as a collective memory and perception filter}

Culture derives from various interrelated systems ${ }^{1}$ (compare fig. 1):

- The system of artifacts, which encompasses everything made by man,

- The system of categories and patterns which guide perception, thought, feeling and behaviour (mentifacts) and

- A system of individuals, who support and express their culture.

With the help of these elements the state of a culture at any given point in time can be described. But this is not sufficient to completely characterize it. For that we also need the activities and processes that render this state possible, such as:

- The skills of producing and using the artifacts,

- The conventions of representation and utilization of the mentifacts, and

- The institutions, roles and rituals which help to carry out the social process.

The various subsystems are not independent from each other: Conventions control the social institutions and determine the functions of the artifacts; these, again, serve as anchors to which culture is manifested and by which it is transmitted. Society as a whole takes up artifacts and mentifacts and adopts them to changing environmental conditions. This occurs within a dialectical process, including everybody and everything perceived as part of a given culture.

Thus, on the one hand, culture functions as a collective memory that helps to advance the systems of artifacts and mentifacts and to pass them on to descendants and contemporaries. On the other hand, the cultural determination of a social system influences the way it comprehends its environment, and in this respect functions as a perception filter. (Posner 1991 a; Assmann/Hölscher 1988).

This function of a perception filter already shows up in the variety different languages use to describe natural phenomenons. The more important a certain environmental, technical or human area is for a society, the more detailed it is comprehended, i.e., the more components are included in the semantic fields as well as in other instruments of representation. The Japanese language, e.g., disposes of numerous expressions to describe the various steps of growth, cultivation and preparation of "rice" (Pelz 1979: 33): "rice plant": ine; "rice seed": momi; "shelled rice grain": kome; "soft-boiled rice": kayu; "boiled rice": meshi, gohan, i-i, mama. And even the areas of the light spectrum are differently covered with terms, although the physiological basis of perception is equal for all men. Not every culture,

\footnotetext{
${ }^{1}$ Compare for the following Posner (1991 a), Werner (1993).
} 
Figure 1:

Constitutive elements of culture

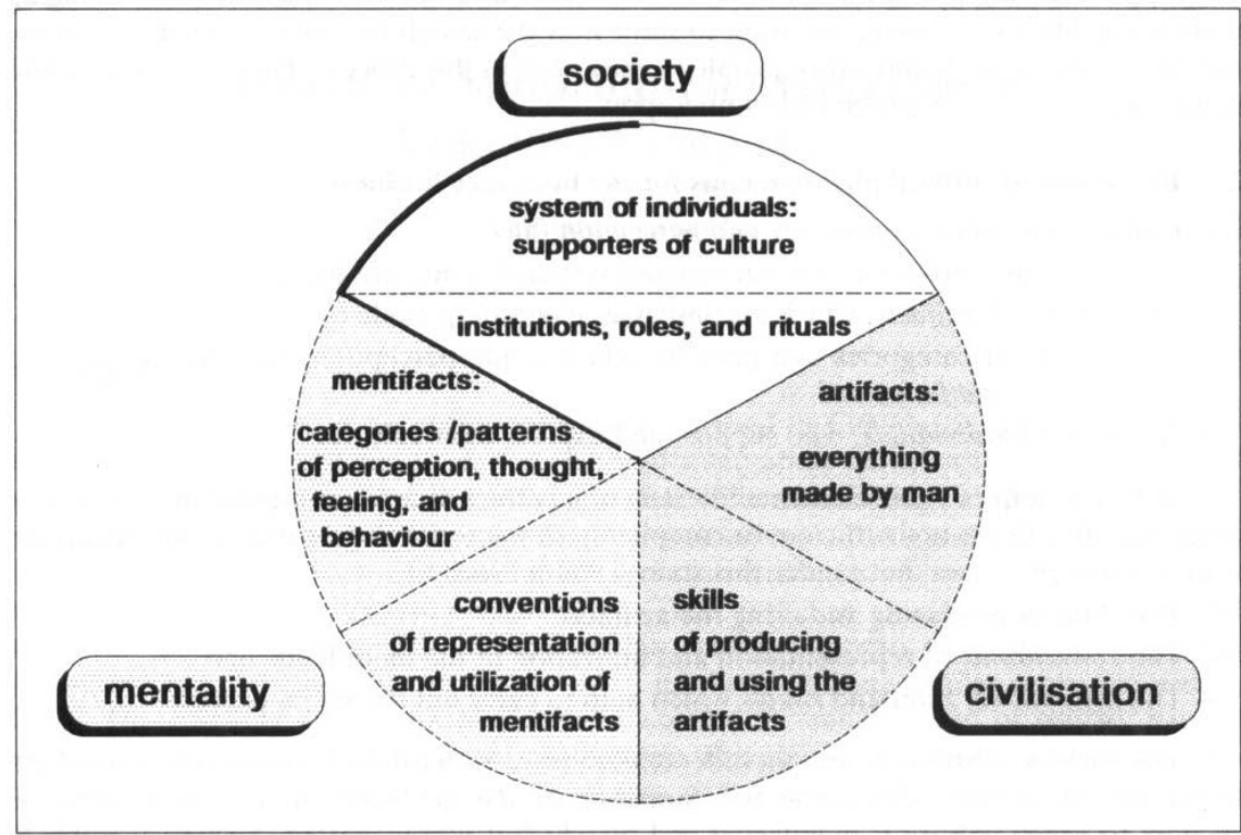

for instance, differentiates between blue and green or between green and yellow like we do (Berlin/Kay 1969). Cymric, e.g., which is spoken in Wales, has only one colour adjective, "glas", for the colours of three objects of which we would describe the first as green, the second as blue and the third as grey (Pelz 1979: 32).

This demonstrates that the areas covered by terms in different languages are not congruent. Consequently, the terms in different languages are not congruent either. Even if the same language is spoken by different cultures, variations in structure, vocabulary, and pronunciation can be found. Examples are British and American English, or Iberian and American Spanish. This may induce curious situations: In Latin America, a Spaniard who wants to politely ask for something (Spanish: rogar), must by his own knowledge use the word for "require" (Spanish: exigir), in order to be understood as intended.

However, more important than such linguistic differences are differences in the patterns of thought, feeling and behaviour. They influence the way in which we interpret the characteristics and actions of others. Identical objects may have variant functions in different cultures. A bicycle may be used predominantly as a sporting of free-time equipment, or it may be considered mainly as a means of transportation. ${ }^{2}$ Everyday shopping may be

2 Waltermann (1989: 197f.) reports an empirical study showing that in Germany and Great Britain a certain brand of car is mainly used as a second, i.e. auxiliary car, whereas in Spain and in the Netherlands it is used as the main or family car. 
regarded as work or as an activity with valuable social functions. Even categories similar in substance like the job, the size of the family and its composition, can result in divergent social positioning (Holzmüller 1986). While in many places on our planet a large family still involves great prestige, in Germany it is not considered a value by itself.

These and other differences demonstrate the necessity of adjusting all marketing activities to cultural contexts. Goods that fit smoothly into the want patterns of the consumers in the supplier's home country will not fit as well in another culture: The institutional framework may vary, the goods may be employed in different situations, for different purposes, and in different combinations. Neglect or even intentional exclusion of cultural differences, such as in the mode of the above mentioned "Global Marketing", may have a counterproductive effect: The supplier cannot achieve standardization by simply doing in other cultures what he does at home. That would only be efficient if the consumers there dealt equally, or at least in a similar way, with the supply like they do in the supplier's country. If this does not hold true, either a leakage has to be accepted or the entire marketing-mix must be adjusted.

Cultural characteristics have to be considered early in the development of a concept for international market research. It is especially important to seize those patterns of thought, feeling and behaviour that become second nature by constant use, and that are therefore taken for granted. Easier to embody are explicit regulations which are formulated for areas considered complex, since they are developed outside of everyday knowledge.

\subsection{Culture-specific risk perception and risk evaluation}

The approach of explicitly considering cultural characteristics in marketing is supported by research on culture-specific perception and rating of risks (McDaniels/Gregory 1991). The resulting risk behaviour, which also comprises decisions for or against insurance, varies from country to country. On the one hand, it is influenced by macro social factors, like the degree of industrialization, the particularities of media reporting or even by certain trends in jurisdiction. On the other hand, there are culture-dependent interpretations of risk characteristics: Common values lead to common fears, and also to a selective perception of certain dangers and their specific rating. ${ }^{3}$

Typically American - since deviating from the specific stamp of the legal system, the contingent fee for solicitors - are, e.g., the enormous premium rates for medical third party insurance in the United States. Likewise, the different reactions of the Germans and the French towards the nuclear reactor accident in Chernobyl could almost have been expected. In Germany the political discourse preceeding this incident dealt, above all, with the risks of nuclear power, whereas France focused on the benefit of this technology, but hardly discussed it.

In general, risk is quantified by means of the parameters "probability of loss" and "possible amount of loss". Yet, many more factors are employed within the intuitive rating of risks (compare fig. 2).

The extent of loss is evaluated by the possible amount of damage, by the space and time

${ }^{3}$ See Douglas/Wildavsky (1983) or the studies of Köcher (1983, 1988) concerning the awareness of danger and the need for security in Germany. For a general outline of the influence of civilization on risk perception see Lübbe (1993). 


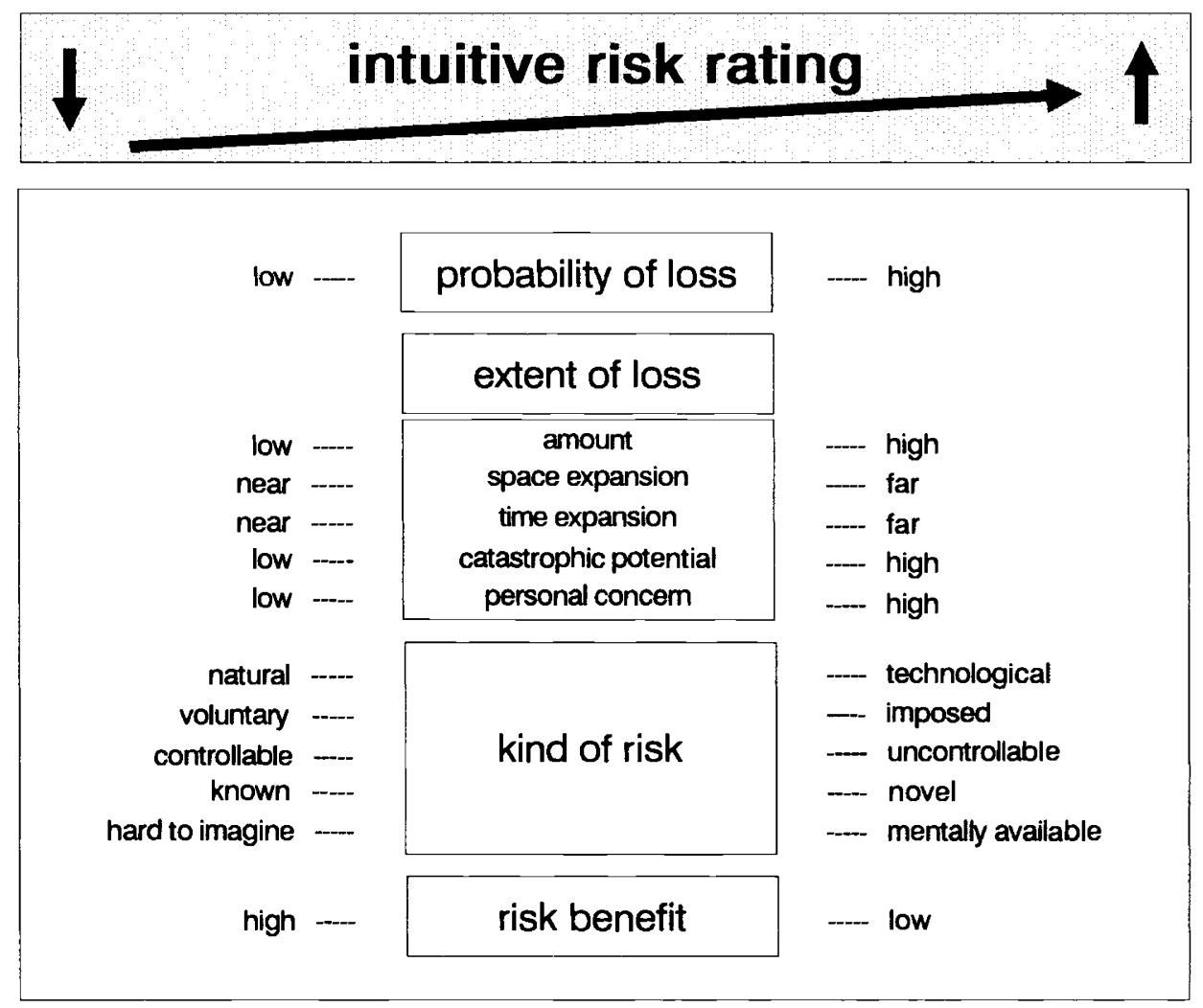

expansion of loss, by its catastrophic potential and by the degree of personal concern. Therefore, intuitive risk rating deviates from the "objective" estimate measured by means of the first two parameters mentioned above (Merkhofer 1987: $20 \mathrm{ff}$.). The higher the probability of loss, the more dangerous the risk is perceived. Among other things, this explains why many people rather wish to take insurance against frequently occurring losses than against low probability events (Urbany/Schmitt/Butler 1989; Slovic et al. 1977; Kunreuther et al. 1978). Risk theory requires just the opposite behaviour. The larger the expansion in space of a possible loss is, the longer its effect prevails, the more people are involved at a time and the sooner the damage can hit, the more threatening the risk appears to be (Jungermann/ Slovic 1993).

Furthermore, the kind of risk plays a part in the intuitive rating process: natural risks seem unavoidable and are therefore more easily accepted than technological, man-made risks. Voluntarily assumed risks and risks that can be influenced are underestimated in 
regards to the dangers they bear. Risks that are laid upon a person externally (e.g., building a nuclear power plant near my house), risks that are considered uncontrollable, that are of an unknown type so that it is hard to picture the consequences of damage: They are overestimated. It also matters to what extent one can benefit from assuming the risk. The mortality risk as a consequence of smoking is therefore rather underestimated whereas the probability of dying in a plane crash is mostly overestimated.

Again, culture influences intuitive risk rating: While novel risks in the United States trigger off public concern, Norwegians seem to evaluate unknown dangers as more or less insignificant and negligible (Teigen/Brun/Slovic 1988; Kleinhesselink/Rosa 1991). Empirical studies also demonstrate that British students are more familiar with the concept of probability than Asian students; they calculate, therefore, the probability of occurrence of certain risks more precisely (McDaniels/Gregory 1991). The experiment of Kunreuther/ Schoemaker (1979) shows that the greater the statistical knowledge, the more calculations enter in the process of risk rating. This result is not as trivial as it may seem, since, if little statistical knowledge is employed in the rating process, it becomes a highly intuitive and therefore culture-dependent way of evaluating risks.

Likewise, risk benefit is interpreted in a culture-specific way: ${ }^{4}$ The "Shop-Garant". e.g., a shopping insurance product introduced to Germany at great advertising expenses, offered an all-risk cover for items paid with a certain credit card. In its country of origin, the United States, this type of insurance seems to operate successfully since an extended product, the "lemon insurance", is being offered there. In this case, the insurer even assumes the expenses for the first repair work that occurs after the expiration date of the legal warranty. In Germany, however, the 90-days all-risk cover resulted in such a high amount of total claims that at first it was limited to a special credit card and, meanwhile, is not being offered anymore (BAV 1991: 78). Concluding a misuse of the product is obvious. This moral risk seems to be relatively high in Germany, at least in the insurance business.

Consequently, not every risk can be covered in every culture. Insurance of human life in an Islamic country encounters ethical problems. Accordingly, neither is a kidnapping, divorce, or loss of drivers license insurance offered in Germany, for this might encourage an "offence against good morals" (BAV 1972: 631, 1981: 31). In addition to the intuitive rating of risks, the concept of time of potential policyholders and the resulting behaviour matters: Not all cultures are ready for a financial sacrifice today in order to avoid it in the future. Going back to anthropological studies, the culture-specific time behaviour has been examined for several years also in regards to its significance for marketing (Usunier 1991; Tse et al. 1988).

\subsection{The cultural character of risks statistics}

The cultural character of risk statistics shall be illustrated by using the example of life insurance. Out of the vast number of biological, physical, and cultural factors that have an impact on life span (compare fig. 3), in most European countries only age and sex are called upon to quantify mortality risk. Increased risks that occur, e.g., with poor health conditions of hazardous jobs are rated by marking up the computed basic mortality.

\footnotetext{
${ }^{4}$ For a comparison of framing effects on Swedish and American subjects see Bohm/Lind (1992); for a discussion of differences in the risk preferences of American, Canadian, and European Businessmen see Laughhunn/Payne/Crum (1980).
} 


\begin{tabular}{|l|l|}
\hline $\begin{array}{l}\text { age } \\
\text { sex }\end{array}$ & $\begin{array}{l}\text { in years } \\
\text { male-female }\end{array}$ \\
\hline residence & $\begin{array}{l}\text { climate - town/rural areas - traffic density } \\
\text { health } \\
\text { occupation } \\
\text { family status } \\
\text { nutrition }\end{array}$ \\
\hline
\end{tabular}

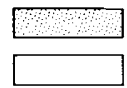

\section{quantification of basic mortality risk \\ subject to cultural influence}

The restriction to only a few tariff factors has information-economical as well as risktheoretical reasons that do not need to be explained further at this time. As a result of this selection, however, the overall effect of the remaining risk factors becomes a random residual, and thus prevents an explicit consideration of cultural particularities in the risk structure. The underlying concept of expected mortality $w$ (d) has the following form: $w(d)=f(a, s, r)$

$$
\text { with } \begin{array}{rlrl}
\mathrm{a} & =\text { age } & & \text { as original risk factor, } \\
\mathrm{s} & =\mathrm{sex} & & \text { as derivative risk factor, } \\
\mathrm{r} & =\mathrm{r}_{\mathrm{bpc}}+\mathrm{r}_{\mathrm{z}} & \begin{array}{l}
\text { total of the remaining risk factors } \\
+ \text { random residual term. }
\end{array}
\end{array}
$$

The expected mortality is shown as a function of: the tariff variables of age and sex, as well as the biological, physical, and cultural risk factors not considered in the tariff $\left(\mathrm{r}_{\mathrm{bpc}}\right)$, and a random residual term $\left(r_{z}\right)$. While age can be regarded as an original risk factor, sex as a tariff feature pictures the effect of several risk factors, since the difference in the mortality between sexes not only originates from biology, but also depends on life style, job, etc. Look at the accommodation of the way of living between men and women in the past which, at the same time, revealed an assimilation of mortality!

Since the expected mortality rates indicated on the mortality tables represent the effect of all risk factors and not only of those used to differentiate the tariff, the mortality tables of different countries, therefore, vary significantly: Compared to Britain, a higher mortality of young men can be observed in Germany (Nonhoff 1991: 257, de Wit 1990: 33). Yet, this does not imply that young English men were more vital than Germans but results from the higher number of road deaths in Germany: One fourth of them is between 18 and 21 years of age (Sievers 1992)! In order to find an explanation for the higher mortality of young German men we have to go back to factors that are not included in the life insurance tariff. 
The higher traffic risk may originate from a lower quality of vehicles or streets, a higher traffic density, insufficient security systems and incompetent schooling, etc.; yet, primarily it has to be traced to the individual traffic behaviour. By far, most accidents in Germany are caused by "non-adjusted speed" (Sievers 1992; Summala 1988: 502). We hypothesize that this behaviour is strongly influenced by culture.

Especially due to the fact that we do not, and perhaps cannot, consider culture-specific particularities, they become relevant. The mortality tables in the European countries do not only look rather different because of the reasons just mentioned above: Sometimes they are based on the mortality of the whole population, sometimes on the data of the companies' insurees. Even the risk factors selected for the construction of the tariff are combined in different ways to form the tariff structure. The British term insurance, for instance, differentiates by the criteria of smokers/non-smokers. Since smoking represents one of the greatest health hazards and the expectation of life for smokers rates significantly below the one of non-smokers, it would be worthwhile to follow the British example and to turn the risk factor "smoking" into a tariff factor. With regard to the French regulations against smoking in public, this may be carried through more easily in France than in Germany.

\subsection{Artifacts and mentifacts in institutions of the insurance business}

Despite the standardization of institutional and legal frames within Europe, risk borders which are essentially cultural borders will continue to exist (de Wit 1990: 35). In what follows, we want to illustrate the content and the extension of these boundaries as well as their consequences.

In our opinion, just those particular risk factors which, contrary to intuition, are not used to differentiate insurance products, point to characteristic traits of cultures. In Germany, public protest and a corresponding judicial decision forced to abandon the idea to differentiate by citizenship in motor third-party insurance (Papier 1982). In the Netherlands, the tariff factor age in health insurance is perceived as a violation of the solidarity principle against elder people (de Wit 1984: 18f.). In the United States, some states, like Montana, do not accept sex as a tariff variable in life insurance, since this is regarded as a discrimination (Black/Skipper 1987: 409; see Cummins et al. 1983).

Likewise, the names given to similar products are culture-dependent. In France, insurance for long-term care of elder persons is, e.g., offered under the trademark "SAFIR" which denotes "security and financial autonomy of retirees". Another product is called "Plan Indépendance" (L'Assurance Française 642/1991: 1271f.). This means that in France, the main function of insuring retirees lies in an active aspect, the independence of elder persons, whereas in Germany the term "Pflege", i.e. nursing, for a comparable product focuses on the dependence of ill retirees.

Furthermore, marketing of insurance products is characterized by a specific way of industrial behaviour that is practiced for a long time and thus taken for granted. In Germany, for example, premiums for life insurance are calculated so cautiously that they can be kept unchanged for a long time. This generates then, at the same time, the policyholders' claim to profit sharing. In Britain, on the other hand, the premium can be computed according to current interest rates and current characteristics of the collective, what makes it variable on a short-term basis. Profit sharing for policyholders has therefore to be mentioned explicitly in the insurance contract, thus altering the premium due (Janotta-Simons 1993). 
This means that insurance companies in the British context are somewhat less restricted in their pricing-policy than under German conditions.

Supervision in regards to the European Single Market also varies from culture to culture. By an early unfreezing of the tariff rates and by easing the legal supervision procedures, French insurers have been able to practice in their domestic market what they would be confronted within the Single Market (L'Assurance Française 642/1991: 1368). In Germany, however, the supervisory office tried to maintain local practice as much and as long as possible, with the consent of the German insurance companies. Such a different degree of opening to foreign markets shows up in the share of international business of the total of premiums collected: in 1985 it was $35 \%$ for British, and $14 \%$ for French companies. For German insurers, however, it was not more than 4\% (Sigma 2/1992: 17). Only in 1991 this quota rose to almost $17 \%$ due to the activities of some important German insurers (GDV 1993: 53).

\section{Fundamentals of insurance marketing in Europe}

\subsection{Customer orientation: The perspective of the policyholders}

The culture-specific way of handling risks should be remembered when a marketing concept for Europe is designed. Psychologists are researching individual risk perception and risk evaluation. Sociologists are working on macrocultural factors; cross-cultural comparisons, however, are seldom drawn. Neither one nor the other is, to our knowledge, sufficiently adopted in insurance theory and practice. This is hard to understand, since the empirical risk behaviour is an important determinant in the decision for or against insurance, and, consequently, for the demand for insurance products.

As early as in 1980, Hoffmann complained that problems in the insurance business were perceived too much from the industries' own point of view. That has not changed to this very day. Yet, in order to pursue a real marketing policy, a changeover from a productoriented view to a customer-oriented way of thinking is necessary. Such a shift of perspectives facilitates the recognition of divergences and problems of coordination between the intended utilization of insurance supply and its situation-determined or culture-specific realization.

Insurance is hard to comprehend, due to its intangibility and to many legal regulations. In addition, signing an insurance contract ties up, sometimes for a long term, a more or less large portion of the policyholder's budget. Likewise, the consequences of selecting a certain insurance product from a certain supplier are hard to judge, so that the benefit realized by insurance may remain below the expectations. The decision for or against insurance therefore reveals characteristics of extensive problem solving (Howard/Sheth 1969: 46; Weinberg 1981: 49-55). Lack of information is reconciled either by a detailed decision process or by means of certain key attributes: The good image of the supplier, an unambiguous product specification, the sophisticated and at the same time partner-oriented attitude of the mediator, and similar factors that indicate quality and thereby assure the decision.

The "country of origin" of insurance products is such a cue: In Spring 1990, a German field survey showed that almost $90 \%$ of the Germans would like to buy insurance exclusively from German companies (Geiger 1991). Little is known about the decision process 
itself, and even less about its culture-specific aspects. Survey research of (potential) policyholders is hardly ever so profound as to draw conclusions about particular determinants of insurance decisions. ${ }^{5}$

Marketing, in our opinion, embraces all activities intended to satisfy needs and desires and to fulfil goals by the exchange of goods. This implies the following: Not only the conditions of the market must be considered but also the organizational, technical, financial and other restrictions of the partners involved in the exchange process. An intensive "look inside" is, therefore, a prerequisite for a customer-oriented marketing of insurance companies. Cost accounting, e.g., has to be extended to a point where estimating of lowest-price limits for specific target groups becomes possible. Furthermore, insurance technology should be reconsidered. Is a certain minimum lot size really necessary for producing insurance? To what extent can the compensation in large homogeneous collectives be replaced or completed by a compensation in time and space, by reinsurance or a solid equity capital base? How about following the idea of portfolio selection theory - trying to establish heterogenous collectives so that the varying degrees of risk of the members of these collectives compensate (Eisen/Müller/Zweifel 1993; Karten 1981)? Could that form the technical basis of a Europe-wide life insurance that might be offered particularly due to the varying mortality rates in the individual countries? This is where risk theory is challenged.

Insurance practice, so far, has attempted to facilitate the tarification process by defining the insured domain as precisely as possible. Such a delimitation of insured perils, property, persons, etc., works also as a specification of the product and thereby serves as a norm for product policy. Based upon a precise definition, the realizations of risks assumed that fall into the insured domain can be considered as a repetition of the same random experiment (Helten 1992). The resulting claims data form the foundation for premium calculation, from which pricing policy is derived.

The insured losses, however, merely represent a subset of the losses of the policyholders and those, again, reflect only a sector of the total set of all losses that might occur in the risk domain (compare fig. 4).

Figure 4: Spheres of risk and damage

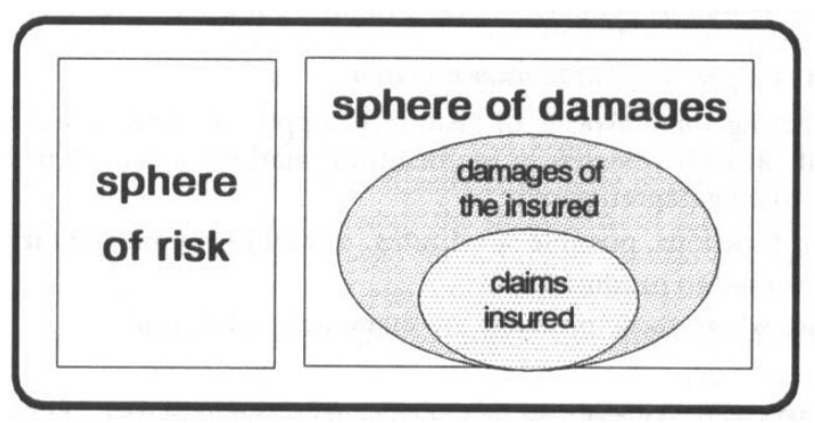

${ }^{5}$ For exceptions see the studies described in Wähling/Trumpfheller/v.d. Schulenburg (1993). For experimental studies of insurance decisions see, e.g. Slovic et al. (1977), Kunreuther/Schoemaker (1979), Einhorn/Hogarth (1986), Wiener/Gentry/Miller (1986), Gentry/Wiener/Burnett (1987), and Camerer/Kunreuther (1989). For American field studies see Urbany/Schmitt/Butler (1989). 
Furthermore, it has to be considered that the marketing concept stands for shaping the offer not only according to unquestionably important technical restrictions and one's own goals, but also according to the need of the market partners, i.e. the actual as well as the prospective insurees. That is only possible by virtue of a wide-span demand research. ${ }^{6}$ Its problems will be outlined in the following chapter.

A customer-oriented view affords innovative potential: Instead of a sound legal definition of the insured domain, imagine an insurance contract specified in an intelligible way, easy to understand for everybody. This could be achieved by means of a simple-to-read, non-technical language, by graphic displays (Haller 1984), and by multi-risk or all-risk covers (as supported, e.g., by Eisen/Müller/Zweifel [1983]). Even though this type of insurance protection were connected to an excess of insurance cover, the policyholder would be able to evaluate such a product better than sophisticated juridical constructions, and he might even be willing to pay a higher price for a benefit he sees more clearly.

So far, there has been little empirical research investigating the price sensitivity of prospective or current policyholders. ${ }^{7}$ The experiments of Einhorn/Hogarth (1986) demonstrate that insurence buyers who are better informed are likely to pay more for insurance of high-probability ( $p>0,35)$ events. The cover of those events constitutes an important market segment, for people rather wish to take insurance against frequently occuring losses than against low-probability events (see 2.2.). But Einhorn/Hogarth (1986) also show that insurance buyers who know little about low-probability events $(p=0,01)$ are ready to pay more than necessary for their insurance. This supports the current market practice of selling mostly unintelligible insurance products. In addition to this, Kunreuther/Schoemaker (1979) report on an experiment that shows the general tendency to pay more in total for three separately offered insurance products than for one multi-risk policy covering the same risk. It is, therefore, partly a question of business ethics to offer good, intelligible products, even if they won't contribute immediately to the maximization of profits. In the long run, however, they may help to stabilize the relations with the clients of the company (Haller 1984), for it is easier to compare prices of products the dimensions of which one can better appraise. Since a heavy price and quality competition is expected in the European market, suppliers as well as demanders may benefit from a customer-oriented design.

\subsection{Possibilities and problems of market research}

After elucidating some aspects of insurance supply, we now turn to the terms of insurance demand: Market research in multicultural markets means that for every culture information has to be gathered about:

- Products, their functions, possible substitutes, as well as complementary products $; 8$

- The techniques used to produce them;

- The institutions where those products are manufactured or traded;

${ }^{6}$ Customer expectations change over time. Zeithaml/Parasuraman /Berry (1990) report of Metropolitan Life Insurance Company which regularly monitors the expectations and perceptions of their custumers in order to anticipate these changes.

${ }^{7}$ See the experiments of Kunreuther/Schoemaker (1979), Einhorn/Hogarth (1986), and Hogarth/ Kunreuther (1989).

8 These are products that are used together in a determinate situation for a common purpose. 
- The norms that guide production, trade and use of those products. In insurance business the regulations concerning insurance contracts and the supervision of insurance companies are part of this.

By virtue of these criteria, differences and common ground in the concept of insurance in different cultures can be pointed out. This is illustrated in figure 5 by example of life insurance in Britain and Germany. ${ }^{9}$

In addition, information has to be gathered about :

- Macro-economic data, such as the level of interest rates, the inflation rate, the tax system, etc.;

- Socio-economic positions, motivations and behaviours of potential demanders.

The recording of socio-economic positions is rather complicated. For a considerable period of time various private organizations and public institutions have been trying to render the national demographic statistics comparable: the EUROBAROMETER of the EC, e.g., deduces the "social position" of citizens mainly from the parameters education and occupation. The "economic position" is determined by the extent to which individual households are furnished with certain material goods. In addition to this, cooperations of private market research institutes (e.g. EUROPANEL, RISC) try to bundle typical attitudes, motivations, and behaviours into a limited number of different "life styles".

An analysis of advertising media may provide insight into local specialities, such as modes of integrating folklore into these media, ways of combining word and picture, or culture-specific styles of colour and design. This market research method helps to determine the communication policy of potential competitors and thereby facilitates the strategic delineation of one's own proceeding.

When primary research is done in a multicultural context, the materials as well as the survey methods have to be adjusted to local conditions. Questionnaires should be translated, of course. But in order to enable the persons being interviewed to interpret the questions like they were intended by the interviewer, at least one independent retranslation into the original language should be done. Furthermore, it must be considered that the categories each culture uses to describe its environment are not identical. Therefore, even rating scales have to be adjusted, i.e. laid out either narrower or wider, depending on how strongly terms are differentiated in varying cultures. Transfer problems exist even in pictures or other illustrations, for these are interpreted according to culture-specific conventions of representation. Different evaluations of colour and form, of gesture and mode of dress, etc., play a part here, too. Yet, even semantically equivalent material can provoke culturespecific reactions of the persons interviewed: the thresholds of tolerance for the length of questionnaires may vary, or courtesy norms could suggest certain tendencies in answering the questions (Holzmüller 1986; Bhalla/Lynn 1987, Schopphoven 1991).

These and other problems of multicultural market research indicate that direct comparisons of data collected without adjustment to the local context cannot be valid. In order to assure similar facts, a category scheme should be established with equivalences in the semantics for several cultures. Despite these problems, neglecting or even deliberately ignoring cultural differences in personal communication, in the motivation for seeking

${ }^{9}$ See also GDV (German Insurance Association) 1992: 38-70. 
Figure 5: Characteristics of life insurance in Britain and Germany

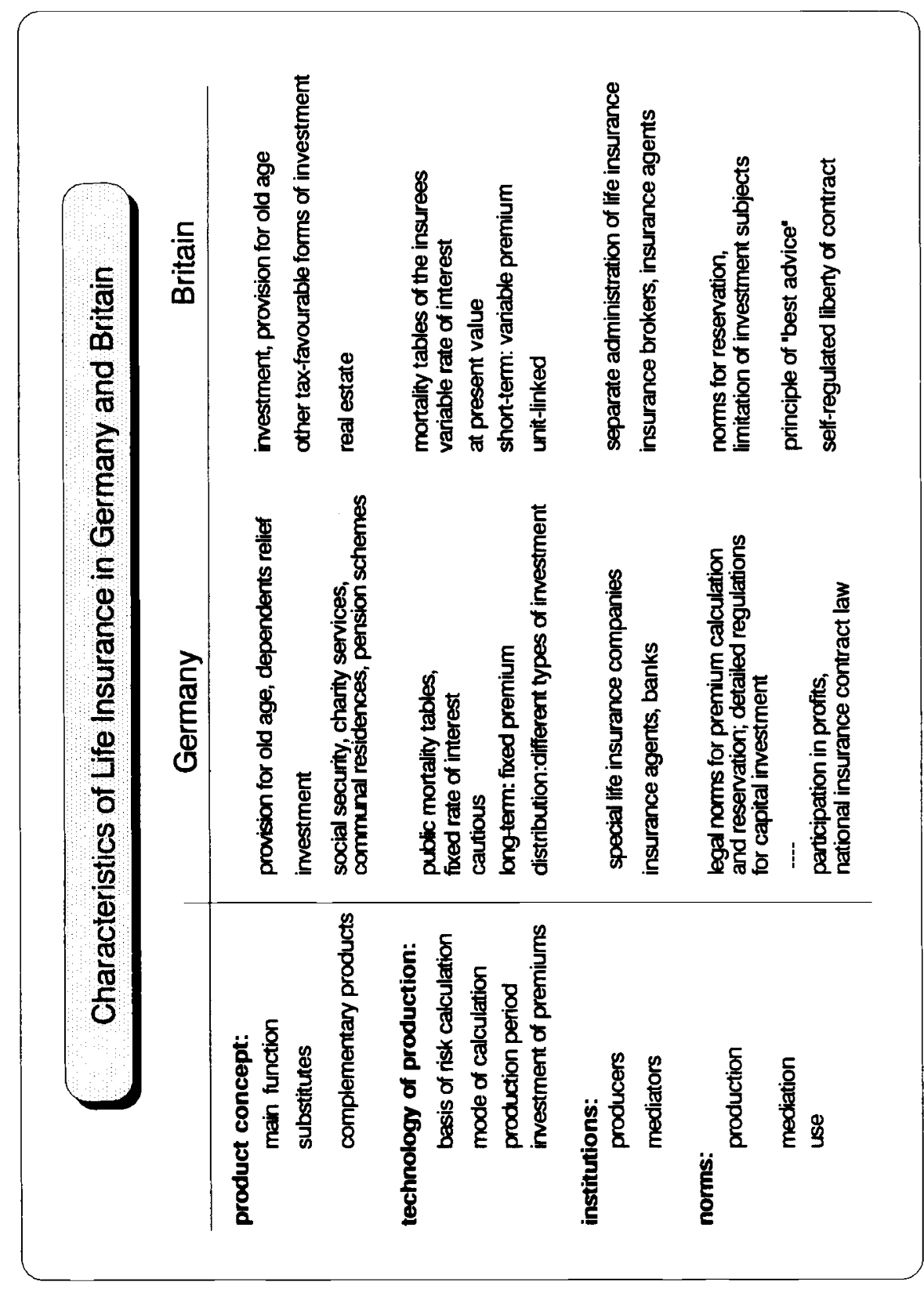


insurance (which may have an impact on product design, advertising and pricing), in buying behaviour, etc., cannot be justified.

\subsection{Adjustment of marketing policy}

As shown above, a broad spectrum of questions and problems must be considered during market research for multicultural marketing. Even harder is the practical realization of knowledge deduced from that phase.

In 1988, Farny surveyed strategies of European insurers for the Single Market. $86 \%$ of the replying companies believed that adaptation to the business practices of the target country would be the preferred strategy for entering the Single Market, and that competition would not only be run by new products but also by distribution and pricing (Farny 1989: 87).

That would be in accordance with the concept of multicultural marketing which does not plead for a complete adaptation to the target market, but suggests to discover new ways that fit into the respective context. In Britain, e.g., insurance is sold predominantly by insurance brokers, whereas German insurance companies are distributing their products mainly with the help of employed salesmen. In Spain, insurance is often sold across the bankcounter. These market structures will change very slowly. For the present they have to be treated as data.

It is surprising, however, that communication policy was not questioned in FARNY's survey and left unconsidered by the responding companies. In German insurance literature, too, the topic of communication policy is treated only in a very step-motherly manner. Even the last booklet on the situation of German insurers in the EC, edited by the German Insurance Association (GDV 1993), explicitly outlines expected changes in product-, price- and distribution policy $(63-70)$, but touches communication policy only slightly in a few words (74). However, in addition to soon becoming the most significant production factor, communication is also a prerequisite for bridging different cultures. Without these bridges, we will not be able to establish the Single European Market.

The predominant activity of practiced multicultural marketing should lie in communication policy, particularly if the number and the diversity of insurance products increase. As long as insurance continues to be a commodity difficult to conceptualize which, on top of that, is related to negative events such as disease, accident, damage to property, etc., it is important to enter into the culture-specific forms of communication used by prospective and current policyholders.

Advertising is a means to make product images fit into different cultural settings. Douglas/Dubois (1977) report on multinational advertising for a small French car: Whereas the prototype campaign in France was based on an amusing "fun" image and realized as a cartoon strip, this humorous picture had to be withheld in other countries where the purchase of cars is perceived as a quite serious affair. In Germany, safety, modern engineering, and interior comfort were emphasized; mechanical features, road handling capacity and acceleration were the main points in Italy.

A car has a lot of "hard-ware" that can be used as cues for advertising. The diversity of the country-specific campaigns mentioned above sheds only a dim light on the fascinating multiplicity immaterial insurance products offer for product positioning and advertising design. This challenge should be taken, for it facilitates the adaptation of insurance products to societal, artifactual, and mental conditions of the target culture. Even if a product 
aims at similar target groups and serves the same needs, cultural differences in the motives for seeking insurance cover can render an universal appeal virtually useless (Douglas/ Dubois 1977: 107). However, word-of-mouth, like personal recommendations or criticism vis-à-vis friends and family members, may be more efficient than wide-spread advertising. ${ }^{10}$

Sometimes the strategy of product branding is applied instead of naming the entire product line after the firm of the insurance company (which may not even be known by everyone). Identification by brand names may help to connotatively widen the sometimes hardly perceivable distinctions between products of different suppliers. It has to be considered, however, that the product name should provoke only fitting associations. The brand "Irish Mist", e.g., given to a motor insurance product of an Irish supplier, may perhaps be appropriate in Ireland but is rather unsuitable in Germany. (The German word "Mist" connotes "trash").

In the process of designing advertising media the culture-specific aesthetics and conventions should be considered and used. French TV spots, for instance, have much more cuts per time unit than German spots, i.e., they run faster. The French are used to that, whereas they soon get bored by the slower German spots (Kloepfer/Landbeck 1991).

Due to the complexity of insurance products, personal communication between insurees and insurance agents is very important. This applies to household business as well as to insurance business. Rules for admitting strangers into the home as well as a strict separation of business and social activities can limit the efficiency of door-to-door sales or other direct sales methods (Douglas/Dubois 1977: 107). Only persons able to meet the adequate style of contacting, negotiating, language, and dress should therefore be selected as mediators.

CAMPBELL et al. (1988) experimentally researched the process and the result of negotiations between German, English, French and American business partners and found a culture-specific meaning of non-verbal elements in communication. The result of negotiations between British partners depends considerably on the assumed roles. British buyers turn out to be significantly more successful than the sales people. In France, however, similarity between negotiating parties (in regards to personality, values, and job experience) increases the success of both buyers and sellers. German partners are obviously facing the conflict between their own and someone else's utility maximization, which has to be negotiated primarily on a verbal level.

These results confirm CATEORA's (1983) classification of communication processes according to their context dependency in different cultures. Following HALL (1976), highcontext cultures like the British culture focus more on non-verbal aspects of the communication process, whereas low-context cultures like the German one, attach more importance on verbal expression. This centering of emphasis must be considered in negotiations between partners from different cultural backgrounds. Besides that, gestures, mimics, proxemics, etc., show context- and culture-specific characteristics, and expression as well as interpretation of those non-verbal elements of the communication process mostly take place unconsciously (Werner 1993).

\footnotetext{
${ }^{10}$ Compare the results of a survey conducted in Germany and reported in Köcher (1982).
} 
More than fifteen years ago, Douglas/Dubois (1977) pointed to the impact of culture on international marketing opportunities. Their comment is still valid, and so we repeat it here once again (108):

"The investigation of cultural influences on market behavior can provide insights and opportunities for international market development and segmentation strategies, as well as clues concerning the pitfalls in positioning, distribution and communication policies. ... Despite this rich potential, the study of cultural influences and the subtle ways in which they channel and pattern market behavior has been largely neglected. Yet, in an age of growing involvement in foreign markets, examination and mastery of these factors should command increased attention from management in designing strategies for the international marketplace."

\section{Appealing for a polycultural Europe}

Production and distribution of standardized insurance products may be cost effective as long as insurance demand is met, more of less. If the market expands over several cultures, this cannot be guaranteed anymore. Then, marketing policy must be adjusted to the cultural frames.

The assimilation of domains for which detailed regulations have been formulated is especially difficult. They prove to be relatively rigid and can be developed only in a limited way. This seems to be one of the reasons why the different national systems of insurance supervision and insurance contract law in Europe have been harmonized to a certain degree only. Now they are exposed to inter-competition. This deserves a great deal of consent, since it helps to maintain the cultural diversity of the European insurance market.

Unlike a "mono-culture", a system with various cultural centers can deal more robustly with environmental changes, e.g. by forming new structures in the different centers and between these centers. A multicultural system shows a wider variety of solutions for certain problems. Problems occurring in particular areas can be antagonized in a rather flexible way. Such a system behaviour presupposes an optimal but not a complete connection of centers formed by institutions and communicative relations. If the network is very dense, the subsystems might slowly assimilate and disturbances could be passed on rather quickly and almost unchanged, turning the entire system to more instability (Goldsmith 1978).

It should therefore be our goal to maintain the multicultural character of Europe despite, or even because of, the increased integration on a societal and civilization level (Posner 1991 b). 


\section{REFERENCES}

ASSMANN, J. and HÖLSCHER, T. (1988, ed.): Kultur und Gedächtnis, Frankfurt.

BAV (1972): Geschäftsbericht 1972, Berlin.

BAV (1981): Geschäftsbericht 1981, Berlin.

BAV (1991): Geschäftsbericht 1991, Berlin.

BERLIN, B. and KAY, P. (1969): Basic Color Terms, Berkeley.

BHALLA, G. and LYNN, L. (1987): Cross-Cultural Marketing Research: A Discussion of Equivalence Issues and Measurement Strategies, Psychology \& Marketing, 275-285.

BLACK, K. and SKIPPER, H. (1987): Life Insurance, Englewood Cliffs.

BOHM, P. and LIND, H. (1992): A Note on the Robustness of a Classical Framing Result, Journal of Economic Psychology, 355-361,

CAMERER, C. and KUNREUTHER, H.C. (1989): Experimental Markets for Insurance, Journal of Risk and Uncertainty, 265-300.

CAMPBELL, N.C., GRAHAM, J.L., JOLIBERT, A. and MEISSNER, H. G. (1988): Marketing Negotiations in France, Germany, the United Kingdom, and the United States, Journal of Marketing, 49-62.

CATEORA, P.R. (1983): International Marketing, 5th ed., Homewood.

CUMMINS, J.D., SMITH, B. D., VANCE, R.N. and VANDERHEI, J.L. (1983): Risk Classification in Life Insurance, Boston.

DOUGLAS, M. and WILDAVSKY, A. (1983): Risk and Culture: An Essay on the Selection of Environmental Dangers, (University of California Press).

DOUGLAS, S. and DUBOIS B. (1977): Looking at the Cultural Environment for International Marketing Opportunities, Columbia Journal of World Business, $102-109$.

EINHORN, H. J. and HOGARTH, R. M. (1986): Decision Making under Ambiguity, Journal of Business, 225-250.

EISEN, R., MÜLLER, W. and ZWEIFEL P. (1993): Entrepreneurial Insurance. A New Paradigm for Deregulated Markets, The Geneva Papers on Risk and Insurance, 3-56.

FARNY, D. (1989): Erwartungen europäischer Versicherer an den Binnenmarkt, Zeitschrift für die gesamte Versicherungswissenschaft, 67-106.

GDV (1992): Lebensversicherungsmärkte in der Europäischen Gemeinschaft, Köln.

GDV (1993): Die deutsche Versicherungswirtschaft im EG-Binnenmarkt, Köln.

GEIGER, H. (1991): EG-Binnenmarkt: Möglichkeiten und Wirklichkeiten, Versicherungswirtschaft, 92-95.

GENTRY, J. W., WIENER, J. L. and BURNETT, M. (1987): The Story, the Frame, and the Choice, Advances in Consumer Research, 14, ed. by M. Wallendorf \& P.F. Anderson, Provo, 198-202.

GOLDSMITH, E. (1978): Complexity and Stability in the Real World, Ecologist Quarterly, 305-316.

HALL, E. T. (1976): Beyond Culture, New York.

HALLER, M. (1984): Ein Selbstverständnis im Wandel: Überlebt die "Gefahrengemeinschaft" als Sinn-Modell der Assekuranz?, in: Rückversicherung - Anspruch und Selbstverständnis, ed. by Eisen und Stahl \& Hannover Rück, Hannover, 23-51.

HELTEN, E. (1992): Versicherungstechnische Möglichkeiten zur Bewältigung künftiger Risiken, Zeitschrift für die gesamte Versicherungswissenschaft, 149-175.

HOFFMANN, W. (1980): Marketing - Aufgabe für das Versicherungsunternehmen heute und morgen, Versicherungswirtschaft, 1109-1115.

HOGART, R.M. and KUNREUTHER, H. (1989): Ambiguity and Insurance Decisions, American Economic Review, 386-390. 
HOLZMÜLLER, H. (1986): Zur Strukturierung der grenzüberschreitenden Konsumentenforschung und spezifischen Methodenproblemen in der Datengewinnung, Jahrbuch der Absatz- und Verbrauchsforschung, 42-70.

HOWARD, J.A. and SHETH, J.N. (1969): The Theory of Buyer Behavior, New York.

JANOTTA-SIMONS, F. (1993): Die versicherungsmathematischen Prinzipien der Dritten EGLebensversicherungsrichtlinie und die künftige Rolle des Versicherungsmathematikers, Zeitschrift für Versicherungswesen, 30-34.

JUNGERMANN, H. and SLOVIC, P. (1993): Characteristika individueller Risikowahrnehmung, in: Risiko ist ein Konstrukt. Wahrnehmungen zur Risikowahrnehmung, ed. by Bayerische Rück, München, $89-107$.

KARTEN, W. (1981): Versicherung - Gefahrengemeinschaft oder Marktleistung?, Versicherungswirtschaft, $1604-1615$.

KLEINHESSELINK, R. R. and ROSA, E. A. (1991): Cognitive Representation of Risk Perceptions. A Comparison of Japan and the United States, Journal of Cross-Cultural Psychology, 11-28.

KLOEPFER, R. and LANDBECK, H. (1991): Ästhetik der Werbung: Der Fernsehspot in Europa als Symptom neuer Macht, Frankfurt.

KÖCHER, R. (1982): Die Versicherungen aus der Sicht der Bürger. Ergebnisse repräsentativer Umfragen Allensbach 1982, ed. by GDV Köln, Karlsruhe.

KÖCHER, R. (1988): Gefahrenbewusstsein und Sicherheitsbedürfnis in Deutschland, Versicherungswirtschaft, $1144-1153$.

KUNREUTHER, H.C., GinsBerG, R., MÜlleR, L., SAGi, P., SLOVIC, P., BORKAN, B. and KATZ, N. (1978). Disaster Insurance Protection: Public Policy Lessons, New York.

KUNREUTHER, H.C. and SCHOEMAKER, P. (1979): An Experimental Study of Insurance Decisions, Journal of Risk and Insurance, 603-618.

LAUGHHUNN, D.J., PAYNE, J.W. and CRUM, R. (1980): Managerial Risk Preferences for Below-Target Returns, Management Science, 1238-1249.

LÜBBE, H. (1993): Sicherheit, Risikowahrnehmung im Zivilisationsprozess, in: Risiko ist ein Konstrukt. Wahrnehmungen zur Risikowahrnehmung, ed. by Bayerische Rück, München, 23-41.

McDANIELS, T. and GREGORY, R.S. (1991): A Framework for Structuring Cross-Cultural Research in Risk and Decision Making, Journal of Cross-Cultural Psychology, 103-128.

MERKHOFER, M. W. (1987): Decision Science and Social Risk Management, Dordrecht.

NONHOFF, D. (1991): Lebensversicherung im EG-Binnenmarkt. Wechselwirkung im Hinblick auf Produkt- und Marktverfassung, Zeitschrift für die gesamte Versicherungswissenschaft, 233-265.

PAPIER, H.J. (1982): Zur Frage der Einführung eines Prämienzuschlags für ausländische Versicherungsnehmer in der Kraftfahrzeug-Haftpflicht-Versicherung, Zeitschrift für die gesamte Versicherungswissenschaft, $461-500$.

PELZ, H. (1979): Linguistik für Anfänger, 3rd. ed., Hamburg.

POSNER, R. (1991 a): Kultur als Zeichensystem. Zur semiotischen Explikation kulturwissenschaftlicher Grundbegriffe, in Kultur als Lebenswelt und Monument, ed. by A. Assmann and D. Harth, Frankfurt, 37-74.

POSNER, R. (1991b): Society, Civilization, Mentality: Prolegomena to a Language Policy for Europe, in: Wanted: A Language Policy for Europe, ed. by F. Coulmas, Berlin.

SCHOPPHOVEN, I. (1991): Marktforschung für das internationale Marketing, Jahrbuch der Absatzund Verbrauchsforschung, 28-47. 
Sigma (1992): Wirtschaftstudien Nr. 2/92, ed. by Schweizer Rück, Zürich.

SIEVERS, H. (1992): Hat Verkehrssicherheitsarbeit Erfolgschancen?, Versicherungswirtschaft, 242-247.

SLOVIC, P., FISCHHOFF, B., LICHTENSTEIN, S., CORRIGAN, B. and COMBS, B. (1977): Preference for Insuring Against Probable Small Losses: Insurance Implications, Journal of Risk and Insurance, 237-258.

SUMMALA, H. (1988): Risk Control is not Risk Adjustment: The Zero-Risk Theory of Driver Behaviour and its Implications, Ergonomics, 491-506.

TEIGEN, K.H., BRUN, W. and SLOVIC, P. (1988): Societal risks as seen by a Norwegian public, Journal of Behavioral Decision Making, 111-130.

TSE, D. K., LEE, K., VERTINSKY, I. and WEHRUNG, D. A. (1988): Does Culture Matter? A Cross-Cultural Study of Executive's Choice, Decisiveness, and Risk Adjustment in International Marketing, Journal of Marketing, 81-95.

URBANY, J.E., SCHMITT, J.T. and BUTLER, D.D. (1989): Insurance Decision (or the lack thereof) for Low Probability Events, Advances in Consumer Research 16, ed. by K. Srull, 535-541.

USUNIER, J.-C. (1991): Business Time Perceptions and National Cultures: A Comparative Survey, Management International Review, 197-217.

WÄHLING, S., TRUMPFHELLER, J. and v.d. SCHULENBURG, J.-M. (1993): Die Nachfragemotive nach Kapitallebensversicherungen und ihre Struktur, Versicherungswirtschaft, 173-180.

WALTERMANN, B. (1989): Internationale Markenpolitik und Produktpositionierung: Markenpolitische Entscheidungen im europäischen Automobilmarkt, Wien.

WEINBERG, P. (1981): Das Entscheidungsverhalten der Konsumenten, Paderborn.

WERNER, U. (1993): Möglichkeiten der Anwendung semiotischer Erkenntnisse im multikulturellen Marketing, Marketing ZPF, 3.1993.

WIENER, J.L., GENTRY, J. W. and MILLER, R. K. (1986): The Framing of the Insurance Purchase Decision, Advances in Consumer Research 13, ed. by R. J. Lutz, Provo, 251-255.

DE WIT, W. (1984): Gesellschaftliche Bedingungen der Prämienkalkulation, Mannheimer Vorträge zur Versicherungswissenschaft, 29, Mannheim.

DE WIT, W. (1990): Die Bedeutung des gemeinsamen Marktes für den europäischen Versicherungskonsumenten, Frankfurter Vorträge zum Versicherungswesen 22, Frankfurt, 23-41.

ZEITHAML, V.A., PARASURAMAN, A. and BERRY, L.L. (1990): Delivering Quality Service, New York. 